\title{
Influence of Economic Factors on Organizational Performance of Airlines: A Case Study Kenya Airways Ltd
}

\author{
Esther N. Mwangi \& Dr Sussy Wekesa \\ Department of Entrepreneurship, Technology, Leadership \& Management, Jomo Kenyatta University of \\ Agriculture \& Technology P.O. BOX 62000-00200 Nairobi, Kenya, Esther N. Mwangi P.O. Box 52790- 00200 \\ Nairobi.
}

\begin{abstract}
The airline businesses depends on the wellbeing of international trade and the stability of the environment in which they operate. Kenya Airways should take great interest in the macro-environmental forces of its markets both locally and internationally. Statistics indicate that Kenya Airways posted kes $25.7 \mathrm{bn}$ loss in the 2014/2015 financial year and this was largely attributed to change in the macro-environmental forces. The effect of macro-environmental forces on the organizational performance of the airline industry especially in Kenya has received little attention in academic research. This study sought to establish the influence of economic factors on organizational performance of Kenya Airways. This study adopted descriptive research design and was limited to two financial years, 2013/2014 and 2014/2015, due to resource constraints. The target population of this study was 245 staff working in Kenya Airways Finance department. Stratified random sampling was used to select 74 respondents. The researcher used a questionnaire as primary data collection instrument. Secondary data was collected from published materials and annual reports of Kenya Airways. Content analysis and descriptive analysis was employed. In addition, a multiple regression was used. The study established that economic factors influence the organizational performance of Kenya Airways Limited. The study also recommends that there is need for government and various policy makers to put in place policies that will improve the economic condition surrounding the airline industry.
\end{abstract}

Keywords: Economic factors, Organizational performance

\section{INTRODUCTION}

The environment of an organization in business is described as "the pattern of all the external conditions and influences that affect its life and development" (Minzberg et al., 2012). The external environment consists of remote forces, that is, the political, economic, social, technological, environmental and legislative, as well as industry forces. Johnson and Scholes (2007) argue that studying these forces is critical and enables a firm evaluate its competitive position vis a vis its strategy, internal resource capabilities and stakeholder acceptability. Miles and Snow (2008) linked positive organizational performance in firms that adapted their strategies faster to external forces than those which did not. The challenge is for firms to ensure a fit or alignment of their strategies and organizational capabilities to external environmental forces. Organizations seek to manage the uncertainty imposed by their interdependence with the environment in two ways: (a) through internal strategies of adaptation and adjustment or organizational design and (b) through external environmental conditions which are important in effective strategic responses by organization (Mitchell et al., 2011; Hough et al., 2003). Organizational performance is a measure of the change of the state of an organization, or the outcomes that results from management decisions and the execution of those decisions by members of the organization (Robert et al., 2006. It is a multi-dimensional construct which can be broken down into financial performance, operational performance and stakeholder performance. Financial performance measures that are commonly used in entrepreneurship and strategic management include profitability measures, growth measure, liquidity measures and cash flow measures.

\section{STATEMENT OF THE PROBLEM}

The external environment in which a firm operates presents the firm with opportunities, threats and constraints. It consists of macroeconomic factors which include political, economic, social, technological, environmental, and legal factors. These have a huge impact on organizational performance of the airline industry and thus, airlines cannot afford to ignore them as they will determine whether or not they sustain competitive advantage. The airline businesses depends on the wellbeing of international trade and the stability of the environment in which they operate. Before creating business plans or when evaluating existing ones it is important to therefore 'scan' the external environment. Volatility of foreign exchange rates, interest rates and fuel prices as well as 
taxation are economic factors which are of great concern to the aviation industry in Kenya. Statistics indicate that Kenya Airways posted kes 25.7bn loss in the 2014/2015 financial year and this was partly attributed to these economic factors. The effect of economic factors on the organizational performance of the airline industry especially in Kenya has received little attention in academic inquiry. Studies done on Kenya Airways have not tackled the issue of the economic factors and their influence on the company's organizational performance (Rajula, 2012; Irungi, 2012; Rono, 2012; Muhia, 2012; Mutia,2011; Kimeu, 2011; Kubai, 2010; Waime, 2010; Gwako, 2008; Gichira, 2007; Ochieng, 2006; Makori, 2006; Chamayiek, 2005). It is in this light that the study seeks to fill the existing research gap by carrying out a study to establish the influence of economic factors on organizational performance of airlines, with special focus on Kenya Airways.

\section{Research objectives}

The main objective of this study was to establish the influence of economic factors on organizational performance of Kenya Airways Limited.

\section{LITERATURE REVIEW}

This study was guided by two theories namely Open Systems Theory and The Resource Based View of the Firm (RBV). The open system theory recognizes that organizations exist in the context of a larger environment that affects how the organization performs and in turn is affected by how the organization interacts with it. The organizational environment is the set of forces surrounding an organization that have the potential to affect the way it operates (Davis \& Powell, 2012). Organizations are ecological entities that have mutual relations with other entities in their environment where they operate as open systems and rely on their environment for their input and market for their end products. The RBV of the firm is a theory that has been explored in the academic literature as a means of explaining competitive advantage and, in turn, superior performance amongst firms. According to Barney (1991), a firm is said to have a competitive advantage when it is implementing a valuecreating strategy not simultaneously being implemented by any current or potential competitors. The model highlights the firm as a unique collection of resources and capabilities, some of which possess the particular characteristics of value, barriers to duplication and appropriability.

\subsection{Conceptual Framework}

\begin{tabular}{|c|c|}
\hline $\begin{array}{l}\text { Economic Factors } \\
\begin{array}{l}\text { - Taxation } \\
\text { - Interest Rates }\end{array}\end{array}$ & $\begin{array}{l}\text { Organizational Performance } \\
\text { - Efficiency } \\
\text { - Growth }\end{array}$ \\
\hline
\end{tabular}

Independent Variable

Dependent Variable

Figure 1: Conceptual Framework

The independent variable in this study is economic factors while the dependent variable is organizational performance. Interest rate fluctuations, national taxation, raw material prices and currency are economic forces which have strong effects on the global market (Yadin, 2002). Taxation has a huge impact on the performance of airlines. Kenyan Parliament had in April 2014 introduced VAT on aircrafts weighing more than 2,000kg, including KQ in the tax bracket that saw it immediately owe the taxman billions as it was in the midst of importing the new aircraft which cost approximately Sh11 billion each. However amendments to the Finance Bill 2014 were passed in August 2014 exempting it from having to pay VAT on aircraft and spare part imports. Interest rate is the price a borrower pays for the use of money they borrow from a lender or fee paid on borrowed assets (Crowley, 2007). KQ's exposure to market risk due to changes in interest rates primarily relates to its cash deposits and borrowings. The interest rate profiles of the company's interest bearing financial instruments include short term and longer borrowings, both of which have fixed and variable rate instruments. An increase/decrease in the interest rates would have an effect on the organizational performance of the company (KQ Annual Report, 2014). Performance is the ability to generate and sustain income, stability and growth (Kithinji and Waweru, 2007). It is a measure of relative investment and can be relative to one of the following factors: assets, capital adequacy, liquidity, liabilities, number of employees and other size measures. Organizational performance in this study is measured in terms of efficiency and growth. Return on Equity (ROE) is one of the ways used to measure efficiency. It indicates how effectively the management of the enterprise is able to turn shareholders' funds into net profit. Growth has long been 
considered a critical and distinct component of organizational performance (Hassan \& Bashir, 2003). Change in revenue will be used as a growth measure in this study. Revenue growth is used to measure how fast a company's business is expanding. It shows the annual rate of increase/decrease in a company's revenue or sales growth and gives analysts and investors ideas of how much a company's sales are increasing over time.

\section{RESEARCH METHODOLOGY}

A research design is the framework for a study that is used as a guide in collecting and analysing data (Kottler \& Armstrong, 2000). Descriptive research design is used in cases where the researcher expected to have the target group explain or describe certain issues about important variables of the study. According to Mugenda and Mugenda (2008) it is important and appropriate to use data where subjects are observed in either natural set ups without manipulating the environment. It can be used when collecting information about people's attitudes and opinions. It is an efficient way to obtain information needed to describe the attitudes, opinions and views of Kenya Airways staff on the influence of economic factors on organizational performance of airlines. This research adopted a descriptive research design where the population of interest who were visited were the employees who work in the Finance Department. The design is deemed appropriate because the main interest was to explore the viable relationship and describe how the factors support matters under investigation. Descriptive design provided quantitative data from cross section of the chosen population.

\section{Research Findings}

\subsection{Demographic Characteristics of Respondents}

The demographic characteristics that were used include age and gender of the respondents, their highest level of education and their level in the organization. From the findings, the study found that most of the respondents as shown by $44.3 \%$ indicated 30 to 39 years, $24.3 \%$ indicated 40 to 49 years, $21.4 \%$ indicated 20 to 29 years and $10.0 \%$ indicated 50 and above years. This is an indication that most of the respondents were well distributed in terms of their age.

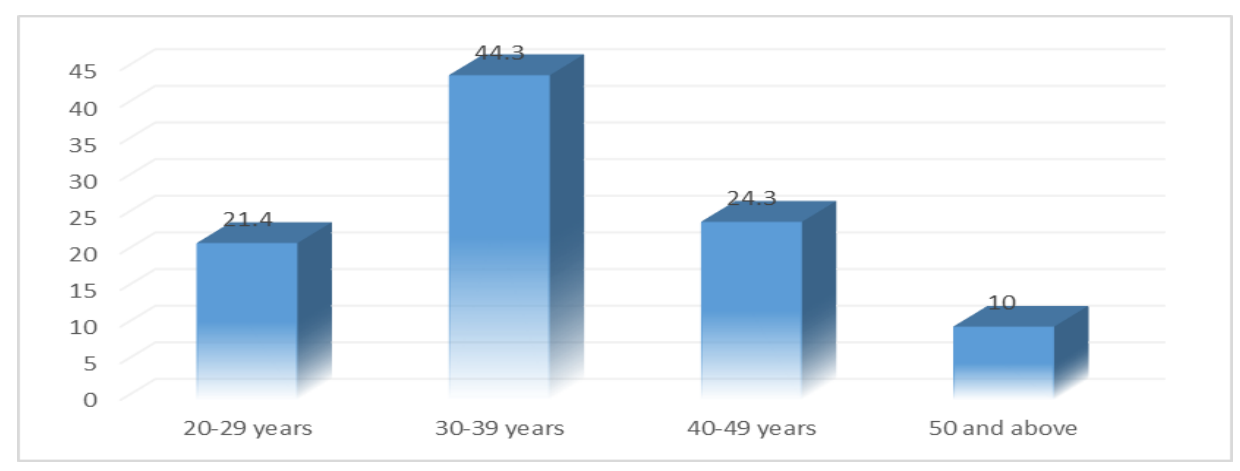

Figure 2: Age of Respondents

The study found that majority of the respondents as shown by $55.7 \%$ was female while $44.3 \%$ were male. This is an indication that both male and female were involved in this study through not in equal proportion and therefore the findings of the study could not suffer from gender biasness.

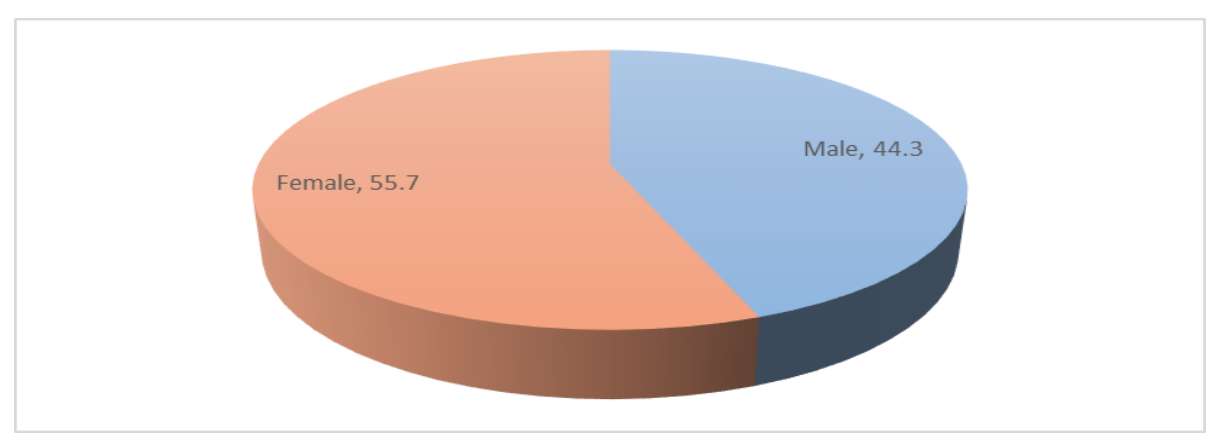

Figure 3: Gender of Respondents

From the findings, the study found that most of the respondents as shown by $40 \%$ had degree, $38.5 \%$ had masters, and $21.5 \%$ had qualifications in other professional courses. This is an indication that most of the 
respondents were learned and they were in a position to understand the questions and give credible information relating to the study.

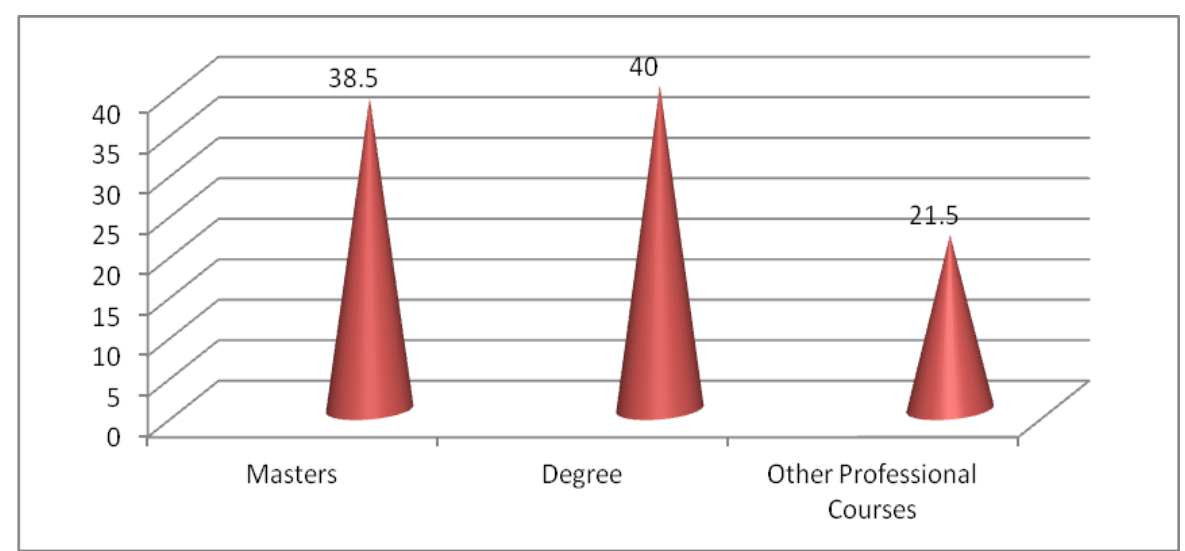

Figure 4: Highest Level of Education of Respondents

The study found that majority were from the low level staff as shown by $47.1 \%, 42.9 \%$ were from middle management and $10 \%$ were top management. This is an indication that most of the respondent were in a position to give credible information relating to the study.

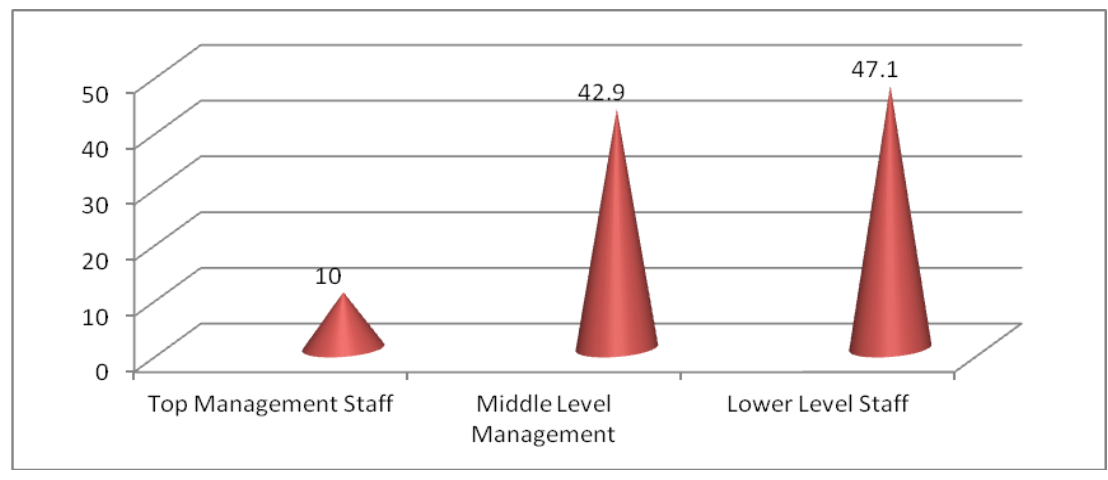

Figure 5: Respondents Level in Organization

\subsection{Descriptive Statistics}

The study sought to establish the extent to which economic factors influence the organizational performance of Kenya Airways Limited. From the findings the study established that majority of the respondents as shown by 45.7 percent indicated very great extent, 40 percent indicated great extent, 8.6 percent indicated moderate extent, and 5.7 percent indicated little extent. The study found that economic factors influence the organizational performance of Kenya Airways Limited to a very great extent. 


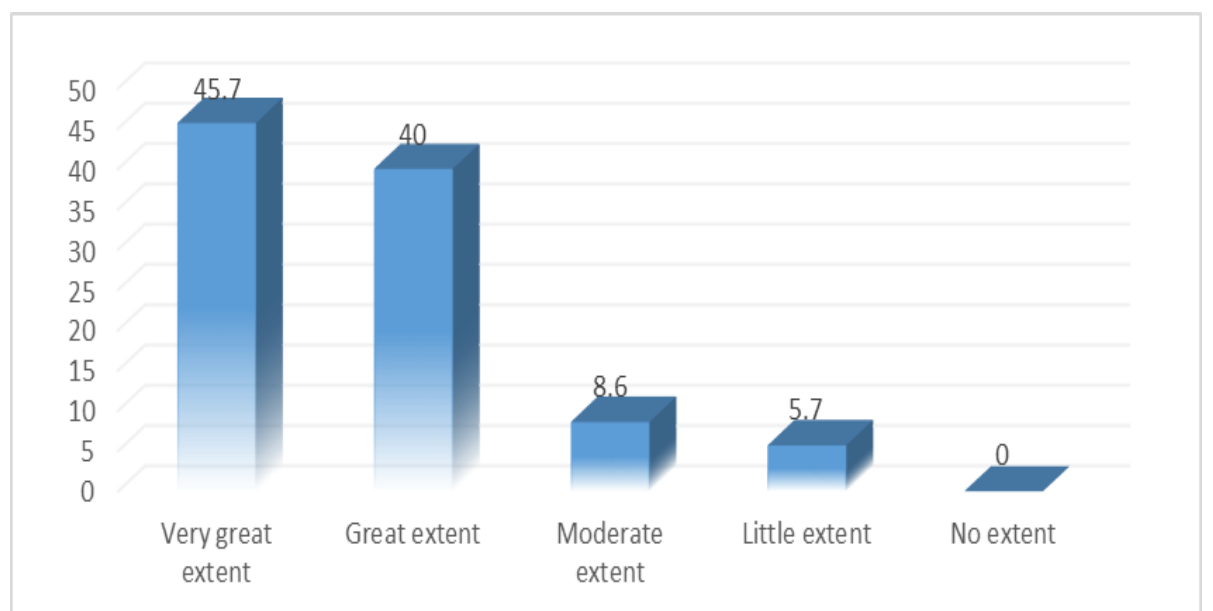

Figure 6: Influence of Economic Factors on Organizational Performance of KQ

Table 1: Influence of Economic Factors on Organizational Performance of KQ

\begin{tabular}{|l|l|l|l|l|l|l|l|}
\hline Statement & & & & & & & \\
\end{tabular}

On the respondent's level of agreement on statements relating to the influence of economic factors on organizational performance of Kenya Airways Limited. The study found that majority of the respondents agreed that the government has a role to play to protect local industries when passing legislation in regards to taxation as shown by a mean of 4.60, increase in interest rates will affect the amount on long term borrowings that Kenya Airways can enter into as shown by a mean of 4.39 , interest rate fluctuations have strong effects on the global market as shown by a mean of 4.36, taxation has a huge impact on the organizational performance of Kenya Airways as shown by a mean of 4.31. The study established that economic factors influence the organizational performance of Kenya Airways Limited, through taxation, interest rate fluctuation and government legislation.

\subsection{Regression Analysis}

The regression analysis for economic factors in relation to organizational performance showed a strong relationship for both efficiency and growth. The results were computed at $95 \%$ confidence level and are summarized and presented in table 2 and 3 below.

Table 2: Economic Factors in relation to Efficiency of Kenya Airways Ltd

\begin{tabular}{|r|c|r|r|r|}
\hline Model & R & $\begin{array}{c}\text { R } \\
\text { Square }\end{array}$ & Adjusted R Square & Std. Error of the Estimate \\
\hline 1 & $.787^{\mathrm{a}}$ & 0.619 & 0.602 & 0.201 \\
\hline a. & Predictors: (Constant), Taxation, Interest Rates \\
\hline b. & Dependent Variable: Efficiency \\
\hline
\end{tabular}


The coefficient of determination was found to be 0.619 . This means $61.9 \%$ of changes in measures of efficiency can be attributed to economic factors. The other variation of $39.1 \%$ is explained by changes in other factors. The coefficient correlation of 0.787 shows that there is a strong relationship between economic factors and efficiency measures of Kenya Airways Ltd.

Table 3: Economic Factors in relation to Growth of Kenya Airways Ltd

\begin{tabular}{|r|c|c|c|r|}
\hline Model & R & $\begin{array}{c}\text { R } \\
\text { Square }\end{array}$ & Adjusted R Square & Std. Error of the Estimate \\
\hline 1 & $.857^{\mathrm{a}}$ & 0.734 & 0.716 & 0.267 \\
\hline a. & Predictors: (Constant), Taxation, Interest Rates \\
\hline b. & Dependent Variable: Growth \\
\hline
\end{tabular}

The coefficient of determination was found to be 0.734 . This means $73.4 \%$ of changes in growth can be attributed to economic factors. The other variation of $26.6 \%$ is explained by changes in other factors. The coefficient correlation of 0.857 shows that there is a strong relationship between economic factors and growth of Kenya Airways Ltd.

\subsection{Findings}

The objective of the study was to establish the influence of economic factors on the organizational performance of Kenya Airways Limited. The study revealed that economic factors have an influence on organizational performance of Kenya Airways Limited. The study further established that the government has a role to play when to protect local industries when passing legislation in regards to taxation, increase in interest rates will affect the amount on long term borrowings that Kenya Airways can enter into, interest rate fluctuations have strong effects on the global market, taxation has a huge impact on the organizational performance of Kenya Airways. Other economic factors mentioned during the study and that may have an impact on organizational performance include the volatility of jet fuel prices and inflation. Fuel prices have been volatile in the recent past and many airlines like Kenya Airways that had taken up hedging contacts stand to lose as prices of fuel dropped drastically. According to IATA, the total fuel cost accounted for $30.1 \%$ of airlines total operating cost in 2013 thus any increase in fuel prices has a huge impact on performance.

\section{CONCLUSION}

The study established economic factors influence the organizational performance of Kenya Airways Limited. These findings were in line with the findings of Yadin (2002), who found that interest rate fluctuations, national taxation, raw material prices and currency are forces that have strong effects on the global market. O'Connor (2000) revealed that other economic forces are stock market values, business cycles, inflation and GDP. The effect is significant talking when about economic forces, size of products and markets as well as the size of the GDP plays an important role in performance of organization in the country. According to Root (2008), taxation has a huge impact on the performance of airlines. An interest rate is a price that relates present claims on resources relative to future claims on resources. Interest rate is the price a borrower pays for the use of money they borrow from a lender or fee paid on borrowed assets (Crowley, 2007). KQ's exposure to market risk due to changes in interest rates primarily relates to its cash deposits and borrowings.

\section{RECOMMENDATION}

The study recommends that there is need for government and various policy makers to put in place policies that will improve the economic condition surrounding the airline industries as the study established economic factors have an influence on organizational performance of Kenya Airways Limited. The study also recommends that there is need for management of Kenya Airways Limited to negotiate better terms for their borrowings as they rely heavily on financing from external borrowings due to huge amounts of capital and cash flow required in the business.

\section{ACKNOWLEDGEMENTS}

I would like to acknowledge the following persons whose contributions facilitated the completion of this project. First, I thank the Almighty God for the gift of life and for giving me the skills, knowledge and energy to be able to complete this paper. Secondly, special thanks go to my supervisor, Dr Susan Wekesa, for providing unlimited, invaluable and active guidance throughout the study. Her immense command and knowledge of the subject matter enabled me to shape this research project. Thirdly, I am blessed with wonderful family and friends who encouraged me and supported my work. My husband, Charles Kikuvi, who has strongly encouraged me and always supported my choices. I also acknowledge my children Bradley, Victoria and Elizabeth for their patience, prayers, and support during my study period. 


\section{REFERENCES}

[1] Barney, J.B. (1991). Strategic factor markets, expectations, luck, and business strategy. Management Science, 42(10), 1231-1241.

[2] Crowley, J., 2007. Interest Rate (2007). Interest Rate Spreads in English- Speaking Africa. IMF Working paper. April 2007.

[3] Davis, G.F., \& Powell, W.W. (2012). Organization-environment relations. In: Dunnette, M.D., \& Hough, L.M. (Eds.). Handbook of industrial organizational psychology, $2^{\text {nd }}$ Ed. Palo Alto, CA: Consulting Psychologists Press.

[4] Hassan, M. K., and Bashir A. H. M. (2003). Determinates of Islamic banking profitability. Paper presented at the Economic Research Forum (ERF) 10th Annual Conference, Marrakesh, Morrocco, 16-18 December.

[5] Johnson, G and Scholes, K (2007). Exploring Corporate Strategy, $7^{\text {th }}$ edition. Harlow, US: Financial Times Prentice Hall.

[6] Kithinji, M. and Waweru, M. (2007). Merger Restructuring and Financial Performance of Commercial Banks in Kenya. Journal of Economics, Management and Financial Markets, 2,(4).

[7] Kotler, P. \& Armstrong, G. (2000). Principles of Marketing, Ninth Edition, Prentice-Hall, Inc., Upper Saddle River, New Jersey 07458.

[8] KQ 2013. Annual Report 2014, September. Retrieved from https://www.kenya-airways.com/global/About Kenya Airways/Investor Information/Investor_News/

[9] KQ 2014. Annual Report 2015, September. Retrieved from https://www.kenya-airways.com/global/About Kenya Airways/Investor Information/Investor_News/

[10] Miles, R.E. \& Snow, C.C. (2008). Organizational Strategy, Structure, and Processes. New York, NY: McGraw-Hill.

[11] Mintzberg, H., Lampel, J., Quinn, J. B., and Ghosal, S., (2012) The Strategy Process: Concepts, Contexts, Cases (4th ed). Essex: Pearson.

[12] Mitchell, J.R., Shepherd, D.A., \& Sharfman, M.P. (2011). Erratic strategic decisions: when and why managers are inconsistent in strategic decision making. Strategic Management Journal, 32, 683-704.

[13] Mugenda, O. \& Mugenda, A. (2008). Research Methods; Quantitative and Qualitative Approaches. Nairobi: Acts Press.

[14] O'Connor, D (2000). Business Planning, Scitech Educational.

[15] Robert B. Carton, Charles W. Hofer, (2006). Measuring Organizational Performance: Metrics for Entrepreneurship and Strategic Management Research. Edward Elgar Publishing Limited.

[16] Root, R. (2008). Entry Strategies for International Markets - revised and expanded. San Francisco, US: Jossey-Bass.

[17] Yadin, D. (2002). The international dictionary of marketing: over 2000 professional terms and techniques. London, UK: Kogan Page. 